\title{
Acis y Galatea: reflexos da Guerra de Sucessão Espanhola na zarzuela de Cañizares-Literes, de 1708
}

\author{
lara Luzia Rodriguez (UFPR, Curitiba, PR) \\ iaraluzia@gmail.com
}

Resumo: o presente artigo busca discorrer sobre a prática músico-teatral na Espanha do início do século XVIII, com foco no estudo da zarzuela Acis y Galatea. Este ensaio pretende demonstrar como o teatro foi utilizado pela dinastia Bourbon para fazer sua propaganda política, incorporando elementos da tradição espanhola, bem como da ópera italiana.

Palavras-chave: Zarzuela; Guerra de Sucessão Espanhola; Teatro e Propaganda.

Acis y Galatea: reflections of the War of Spanish Succession in the Cañizares-Literes's zarzuela, 1708

Abstract: this article attempts to discuss the musical-theatre practice in Spain during the early Eighteenth Century, emphasizing the zarzuela Acis y Galatea. It also intends to show how the theatre was used by the Bourbon dynasty for its propaganda, incorporating elements of the Spanish tradition and Italian opera.

Keywords: Zarzuela; War of Spanish Succession; Theatre and Propaganda.

\section{O Teatro: um instrumento de propaganda monárquica}

Desde o século $X V$, época em que as primeiras companhias e autores de teatro profissionais passaram a atuar na Península Ibérica, as representações cênicas estavam diretamente ligadas à difusão de uma determinada ideologia. Neste período, dominado fundamentalmente pela Igreja Católica, as principais peças teatrais na Espanha eram os Autos Religiosos.

No século XVII, com a chegada de Felipe IV ao trono espanhol e a presença de uma monarquia mais poderosa no país, o teatro passa a ser um dos principais meios de propaganda política da coroa. Não é por acaso que é durante este período que foram representadas as primeiras óperas espanholas, sempre ligadas a importantes acontecimentos políticos, como casamentos e alianças entre os monarcas ${ }^{1}$.

As representações teatrais eram, portanto, uma afirmação do poder da nobreza $^{2}$, e, em especial do rei, constantemente apresentado através da utilização de divindades nas peças teatrais, justificando o porquê da preferência pelos temas mitológicos. Neste sentido, o teatro barroco espanhol é mais que "um mero entretenimento, mas um sistema de representação de um programa político que transmite uma determinada visão do mundo e do papel do monarca sobre o mesmo." 3 (ASENSIO, 2004, p.11). 
No teatro barroco espanhol percebe-se uma organização fixa muito rigorosa, cuja estrutura básica é observada em grande parte das peças do período, inclusive naquelas pertencentes aos gêneros músico-teatrais. Uma vez que as obras teatrais deveriam refletir a monarquia, bem como o papel que esta exercia perante a sociedade, esta organização formal no teatro, mesmo que intrinsecamente, desempenhava uma função de caráter didático e moralizante para a população. Ou seja, um teatro organizado, com normas rígidas e bem fixado, transmite a mesma ideia com relação ao governo desempenhado pelo monarca.

Não é coincidência que o modelo da comedia nueva, instituído por Lope de Vega, é seguido por todos os dramaturgos ao longo do século XVII e início do século XVIII. O mesmo é verificado nas peças que misturam momentos de canto com os de fala, como é o caso da zarzuela. Elas conservarão as regras de Lope, juntamente com as normas que Calderón de la Barca estabelece para estes gêneros híbridos. ${ }^{4}$

O período em questão foi uma época de grandes monarquias absolutistas na Europa, nas quais o rei representava uma figura quase divina, unindo todos os poderes em suas mãos. Logo, a figura do monarca deveria ser refletida da mesma maneira no teatro. Portanto, as produções eram custosas, com diversas mudanças de cenário, trajes pomposos, fundamentais para enaltecer a magnificência do rei, bem como salientar a ideia do "maravilhoso", elemento retórico bastante utilizado para persuasão, de acordo com LOPEZ CANO (2000).

Nada ocorria por acaso, isto é, no teatro espanhol do século XVII e, principalmente, nas primeiras décadas do XVIII, tudo era previamente organizado, desde os gestos dos atores e atrizes ao local em que o espetáculo seria apresentado, e, até mesmo a música possuía suas próprias convenções a serem seguidas, uma vez que a mesma "geralmente refletia os debates políticos, sociais e econômicos”. (BUSSEY, 1980).

As obras teatrais funcionavam também como um espelho da sociedade, logo, é possível compreender porque a ópera italiana não foi bem aceita no país, resultando na criação de gêneros híbridos, como a zarzuela, e, mais que isso, a resistência, em especial por parte da Igreja ${ }^{5}$, em relação à influência estrangeira sobre a tradição espanhola.

Acis y Galatea foi composta durante uma época bastante conturbada na história da Espanha, que foi a transição da dinastia Habsburgo para Bourbon. Em muitos momentos, esta zarzuela faz menção a eventos que realmente aconteceram, além de também assumir um caráter propagandístico, buscando sempre a ascensão da figura do rei. 


\section{A Música no Teatro: mais uma ferramenta política}

A música no teatro espanhol, como afirmam ASENSIO (2004) e STEIN (1993), é mais do que um mero elemento de ornamentação, e, a ela são atribuídas diversas funções, que podem estar relacionadas à trama (para, por exemplo, abrir e fechar cenas), aos personagens (para apresentá-los e caracterizá-los), ou ainda, embora, de forma não tão evidente, à ideologia.

O papel exercido pela música com relação à ideologia pode acontecer de duas maneiras. Em um primeiro momento, foi utilizada como um elemento de louvor e consagração da figura do rei e da monarquia. A principal função ideológica da música refere-se à doutrinação da população.

A música promoveu os benefícios morais, políticos e educacionais do gênero através do reforço da verossimilhança teatral (essencial para as artes barrocas espanholas em geral) com o realismo afetivo em cenas que refletiam as expressões da vida real. Por formar uma associação imediata entre o palco e o dia-a-dia, as canções conhecidas da época, dominavam o repertório musical da comedia. (STEIN, 1993, p.13)

Para melhor compreender como a música adquiriu essa característica doutrinária, deve-se tentar entender a mentalidade dos dramaturgos da época. As zarzuelas possuíam dois elementos formadores bem diferentes entre si, o cantar e o declamar. A declamação está diretamente relacionada à fala, e, é nesta ocasião em que a história se desenvolverá. Os momentos de canto, por sua vez, estarão conectados à música e, em geral, eles acontecem quando a cena pede um elemento mais forte de persuasão.

Este poder persuasivo se consegue mediante a perfeita simbiose entre a letra cantada e a música (...). Não deve, portanto, surpreender-nos, que os poemas cantados protagonizem as declarações amorosas, já que, tanto para comunicar os próprios sentimentos, como, sobretudo, para tornar alguém apaixonado, o poder da música parece ter sido irresistível. (ASENSIO, 2004, p.741)

Devido a essa característica persuasiva, resultante da junção entre poesia e música, as canções $^{6}$, em especial, eram utilizadas como um meio de doutrinação. A principal ideia a ser transmitida ao público era colocada no estribilho, já que este seria repetido diversas vezes durante a obra, ou ainda, em uma melodia conhecida pelo público, inseria-se um novo texto, como já era observado nas obras de Calderón de la Barca. A presença de canções populares torna-se um elemento fundamental no teatro espanhol.

A música exercia uma função simbólica bastante importante nas peças de teatro, que, de certa forma, está ainda ligada à ideologia. Canções mais complexas, em geral Árias da Capo, vinculadas aos estrangeirismos, caracterizariam simbolicamente os personagens divinos, logo, a monarquia e a nobreza, os únicos que seriam capazes de compreender tais formas. Enquanto as canções mais simples, muitas vezes já conhecidas pelo público, seriam 
cantadas pelos personagens vulgares, representando o povo. As músicas para coro, por outro lado, simbolizariam "uma voz impessoal, bem como a manifestação do destino, da consciência, ou como voz divina que avisa, aconselha e estimula o homem a cometer uma ação ou evitá-la". (ASENSIO,2004, p.749)

Em Acis y Galatea, esses elementos serão encontrados, como será exemplificado adiante, caracterizando-a, portanto, não só como uma zarzuela festiva, mas também como uma obra com função social e política.

\section{Acis y Galatea: uma obra política}

O princípio da verossimilhança, talvez o mais importante da convenção teatral espanhola, regia a elaboração das obras teatrais em toda Espanha. Observase em diversas peças músico-teatrais deste período, referências claras a acontecimentos políticos ocorridos na época, como é o caso de Acis y Galatea.

Esta peça, composta em 1708, para comemoração do aniversário do rei Felipe $\mathrm{V}$, além de apresentar várias cenas que podem ser associadas a fatos decorridos no período de elaboração da mesma, tornou-se um meio propagandístico do monarca. Entretanto, nem todas estas referências aparecem de maneira direta na obra, estando presente, muitas vezes, através de metáforas.

A música foi composta por Antonio Literes (1676 - 1747), Mestre da Capela Real em Madrid, com o libreto de José de Cañizares (1676 - 1750), renomado dramaturgo espanhol do século XVIII, baseado no conto homônimo de Ovídio. Neste o ciclope, Polifemo, lamenta-se por não ser amado pela ninfa Galateia, a qual, por sua vez, é apaixonada pelo pastor Ácis, que acaba sendo morto devido ao ciúme do gigante. Muitas diferenças serão encontradas na releitura espanhola, todas sendo justificadas pelo caráter propagandístico que a mesma adquire.

No trecho abaixo há uma clara exaltação ao rei. Neste, uma nereida ${ }^{7}$ do séquito de Galateia pede para que se cantem todas as façanhas de Felipe V.

Si el triunfo que ama

veloz la fama

con bronce aclama,

pues le posee, gorjee,

que de la España

la mayor gloria

será la hazaña

de su memoria,

cuando en Philipe su aliento emplee. ${ }^{8}$

\author{
Se o triunfo que ama \\ veloz a fama \\ com bronze aclama, \\ pois o possui, gorjeie, \\ que da Espanha \\ a maior glória \\ será a façanha \\ de sua memória, \\ quando em Philipe seu alento empregue.
}

Este é um dos poucos momentos da zarzuela em que se verifica o uso de coloraturas, justificadas, claramente, pelo texto. Estes ornamentos sobre gorjee, além de representarem o verbo de forma musicalmente coerente, 
tornam-se uma representação mimética do mesmo, um exemplo claro de pintura de palavra, muito comum nos madrigais renascentistas. Eles funcionam ainda como um elemento retórico para enfatizar o seu significado, ou seja, que se cante (gorjeie), mundo afora, todas as glórias do rei. A repetição da frase pelos violinos intensifica esta ênfase, passando a ideia de que todos devem cantar as façanhas de Felipe $\mathrm{V}$, como pode ser observado no Ex.1 abaixo.
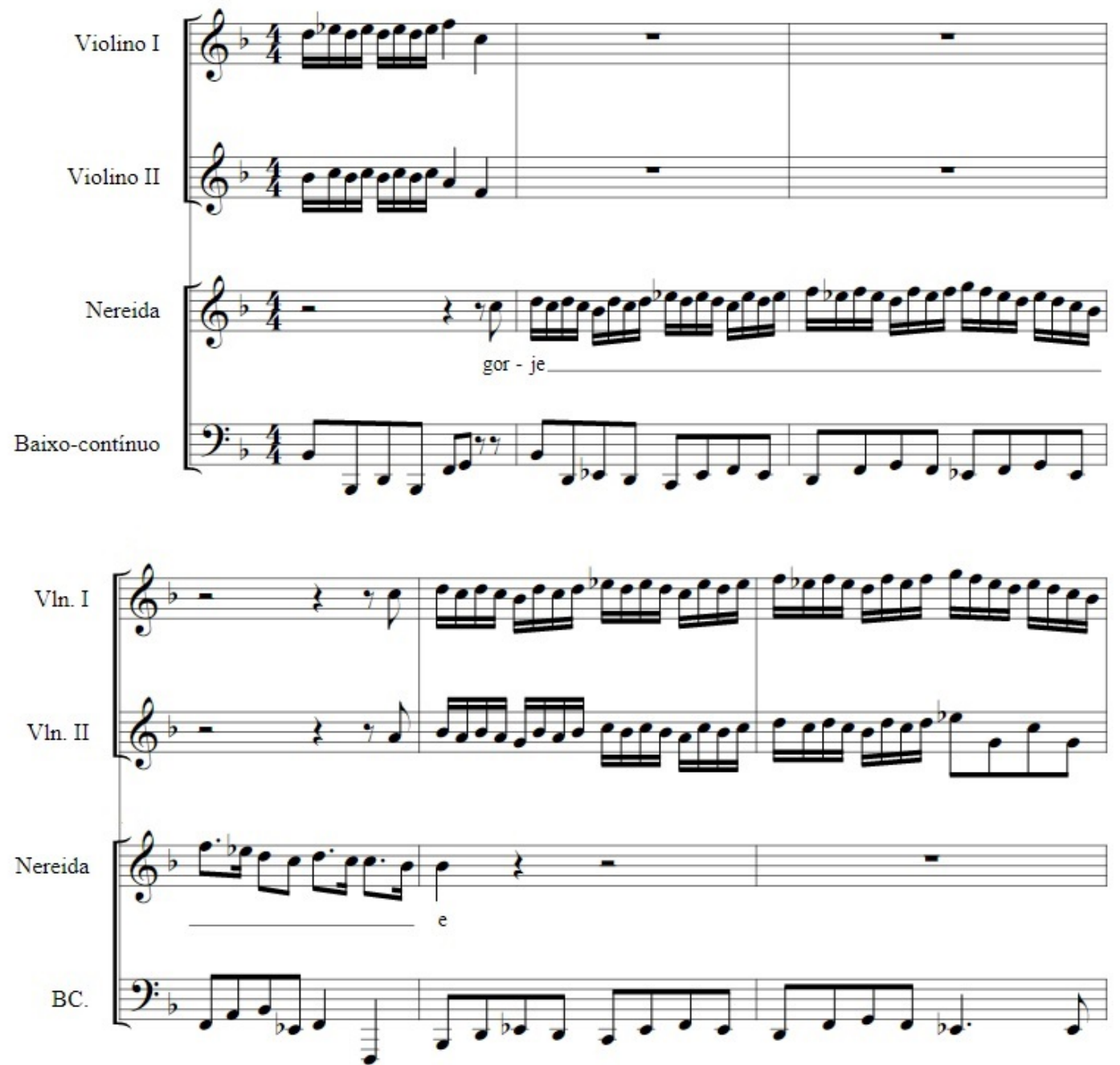

Ex. 1 - José de Cañizares e Antonio Literes. Acis y Galatea. Aria de uma nereida: Si el triunfo que ama, c.85-90, p.187.

Esta prática difere bastante da ópera italiana do mesmo período, na qual as ornamentações vocais prevaleciam sobre o texto. Aqui, no entanto, observa-se que nos momentos em que há mais poesia, há pouca ou nenhuma ornamentação, não comprometendo, portanto, a compreensão do ouvinte, como pode ser verificado no Ex. 2: 

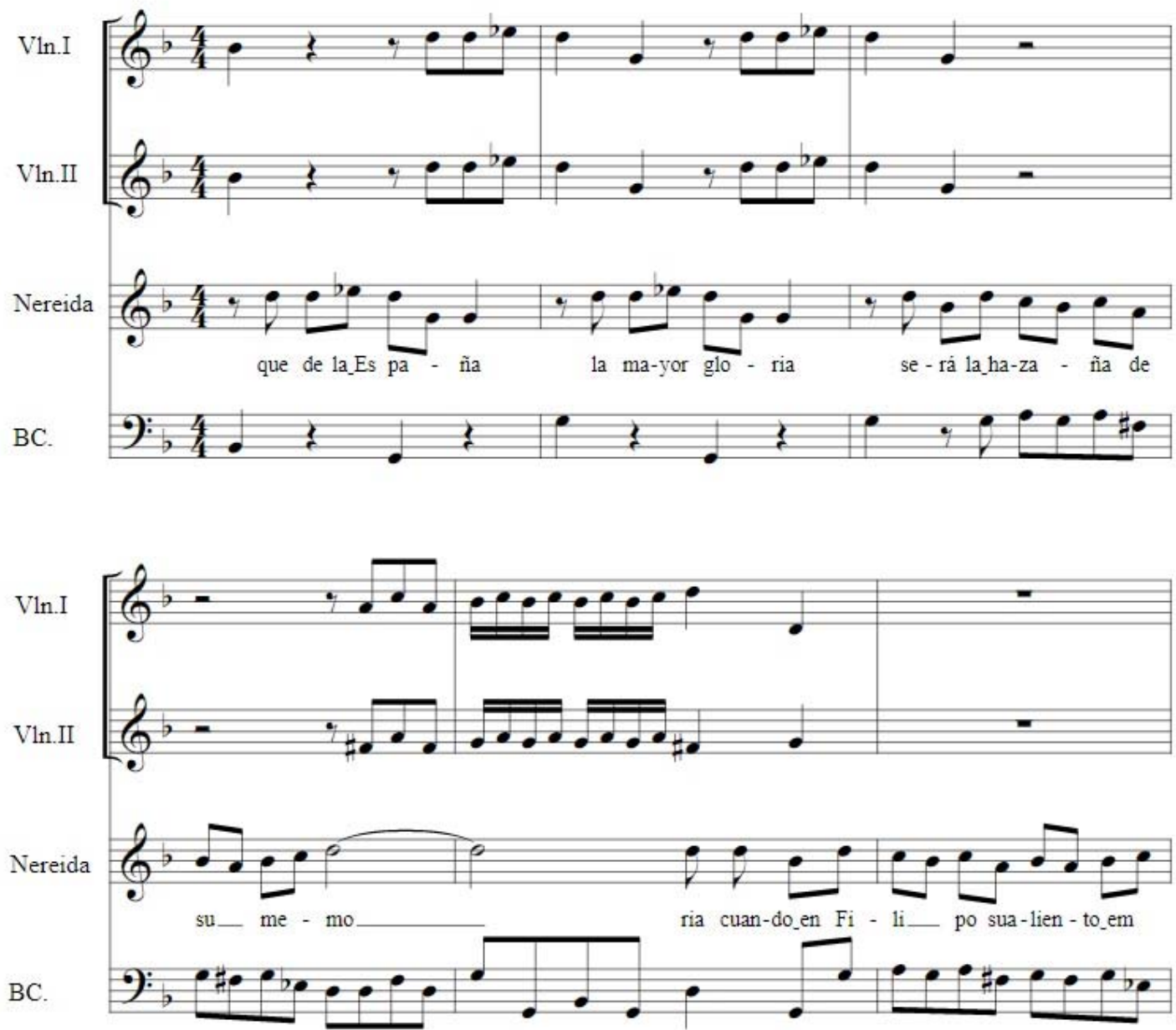

Ex. 2 - José de Cañizares e Antonio Literes. Acis y Galatea. Parte B da Ária Si el triunfo que ama, c.97-102, p.188.

$\mathrm{Na}$ passagem abaixo, existe uma clara referência ao aniversário do rei. A personagem, novamente uma nereida, homenageia o monarca, através das mensagens de sucesso e glória, evocando, inclusive os deuses mitológicos.

De María Luisa y de Luis los abrazos dulces coronen al héroe mayor, porque la dicha más noble del uno es la fineza inmortal de los dos
De Maria Luisa e de Luis $^{9}$ os abraços doces coroem ao herói maior, porque a felicidade mais nobre do um é a bondade imortal dos dois

Nota-se uma pequena divergência entre o libreto encontrado em Madrid e o que se situa na biblioteca de Évora ${ }^{10}$. É possível que tenham ocorrido modificações, tanto na partitura, como no libreto, pois, de acordo com González Marín ${ }^{11}$ (2002), provavelmente a edição original de Acis y Galatea, tenha sido perdida e esta é possivelmente de alguma representação posterior.

No libreto da Biblioteca Pública de Évora, encontra-se uma clara referência aos sucessos do rei francês, Luis XIV, também conhecido por Rei Sol. Felipe V, sendo neto do monarca francês, e devido à troca de dinastia da coroa 
espanhola para Bourbons, não mais Habsburgos, a alusão a Luis XIV torna-se bem clara, através da metáfora "reflexos o Sol".

Manuscrito da Biblioteca Pública de Évora:

Y a sus laureles de palma y oliva orlas formando de regio esplendor, Marte la rinda gloriosos trofeos, triunfos la Fama y reflejos el Sol.
E aos seus louros de palma e oliveira orlas formando de real esplendor, Marte o renda gloriosos troféus, triunfos a Fama e reflexos o Sol.

Marte, de acordo com a mitologia romana, é o deus que representa a guerra. Logo, este trecho está diretamente ligado à situação política espanhola, pois, desejar que Marte lhe dê muitos troféus, é o mesmo que desejar ao soberano, vitória nas diversas batalhas, contra a dinastia austríaca, que ocorriam pela coroa espanhola, como será detalhado mais adiante.

A Fama, por sua vez, é a figura mitológica que se encarregava de contar para todos, dia e noite, as novidades que via com seus vários olhos e ouvia, através de suas diversas orelhas. Portanto, nesta passagem, deseja-se ao rei, que seus triunfos sejam narrados incessantemente e que sejam de conhecimento de todo o mundo.

Entretanto, no manuscrito existente na Biblioteca Nacional de España é encontrado um texto diferenciado.

Manuscrita da Biblioteca Nacional de España:

Y uniendo al laurel pacífica oliva, de regios pimpollos ceñida y orlada, Minerva le postre afables inciensos, y Marte guerrero le rinda holocausto.
E unindo ao laurel pacífica oliveira de reais galhos justa e adornada, Minerva o prostre afáveis incensos e Marte guerreiro o renda holocausto.

Novamente, encontra-se uma alusão aos deuses mitológicos. Minerva é a divindade romana das artes, da sabedoria e também da guerra, mas diferentemente de Marte, ela representa a guerra justa e diplomática, enquanto seu irmão está associado à guerra de maneira mais violenta e sangrenta. Por isso, "Minerva prostrar afáveis incensos" tem um significado muito forte, insinuando que até mesmo as artes, a sabedoria e a guerra se curvariam em adulação ao monarca.

Não se sabe o motivo para a ausência à menção ao rei francês, que pode ter um fundo político, ou pode ser simplesmente a adaptação mais adequada do libreto à música, como defende o editor da versão crítica da partitura: "em minha transcrição utilizei o texto de Madrid, que encaixa melhor com a música" (GONZÁLEZ MARÍN, 2002, p.XIX).

Nos Ex.3 e Ex.4, é possível notar como a ideia exposta pela voz é reforçada pelos violinos. 
Nereida

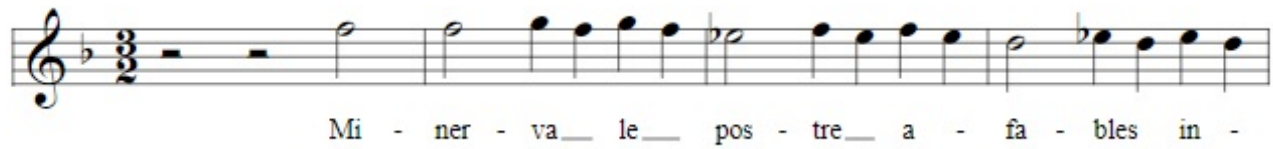

Ex. 3 - José de Cañizares e Antonio Literes. Acis y Galatea. Final da Zarzuela: Viva quien hace siglos de dichas sus años, c.22-25, p.192.

Esta forma de ênfase, com uma mesma frase repetida por outra voz é um elemento bem comum, encontrada em diversos momentos desta zarzuela.

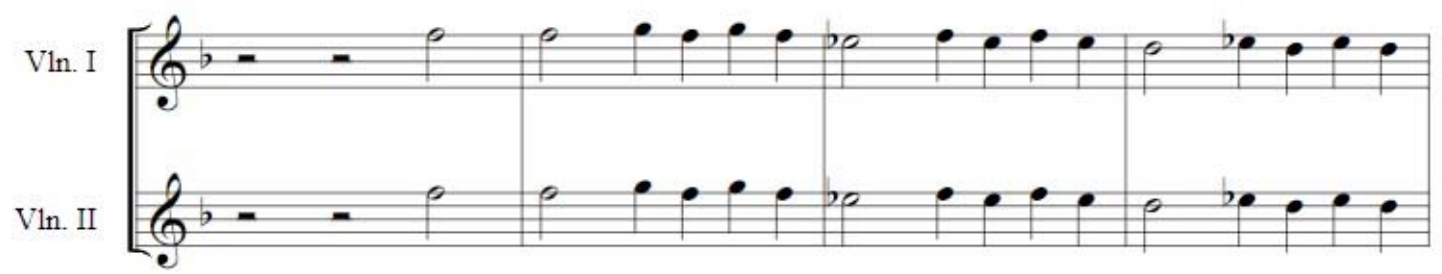

Ex.4 - José de Cañizares e Antonio Literes. Acis y Galatea. Repetição da melodia enfatizada pelos violinos, c.30-33, p.192.

Além de celebrar o aniversário do rei, esta zarzuela tem uma função social muito importante, que é a de demonstrar os seus grandes feitos, bem como, refletir, através da obra, a boa índole do monarca. Como já foi dito anteriormente, a Espanha estava passando por uma troca de dinastia, portanto, era fundamental demonstrar à corte e à população os benefícios desta mudança.

Em Acis y Galatea, há certas referências a fatos, de maneira mais discreta. Uma delas está logo no início da primeira jornada ${ }^{12}$, onde Polifemo, após sua volta a Trinacria ${ }^{13}$, depara-se com a população prestando homenagens a Galateia (ver Ex. 5).

No hay otras iras que deban temerse en cielo y en tierra que los activos incendios que exhalan los ojos de Galatea.
Não há outras iras a temer no céu e na terra que os incêndios ativos que lançam os olhos de Galateia.

Durante todo este trecho, o coro, bem como os instrumentos permanecem em homofonia e, preponderantemente, com movimentos em grau conjunto, distinguindo-se da polifonia, ainda comum nas igrejas. 


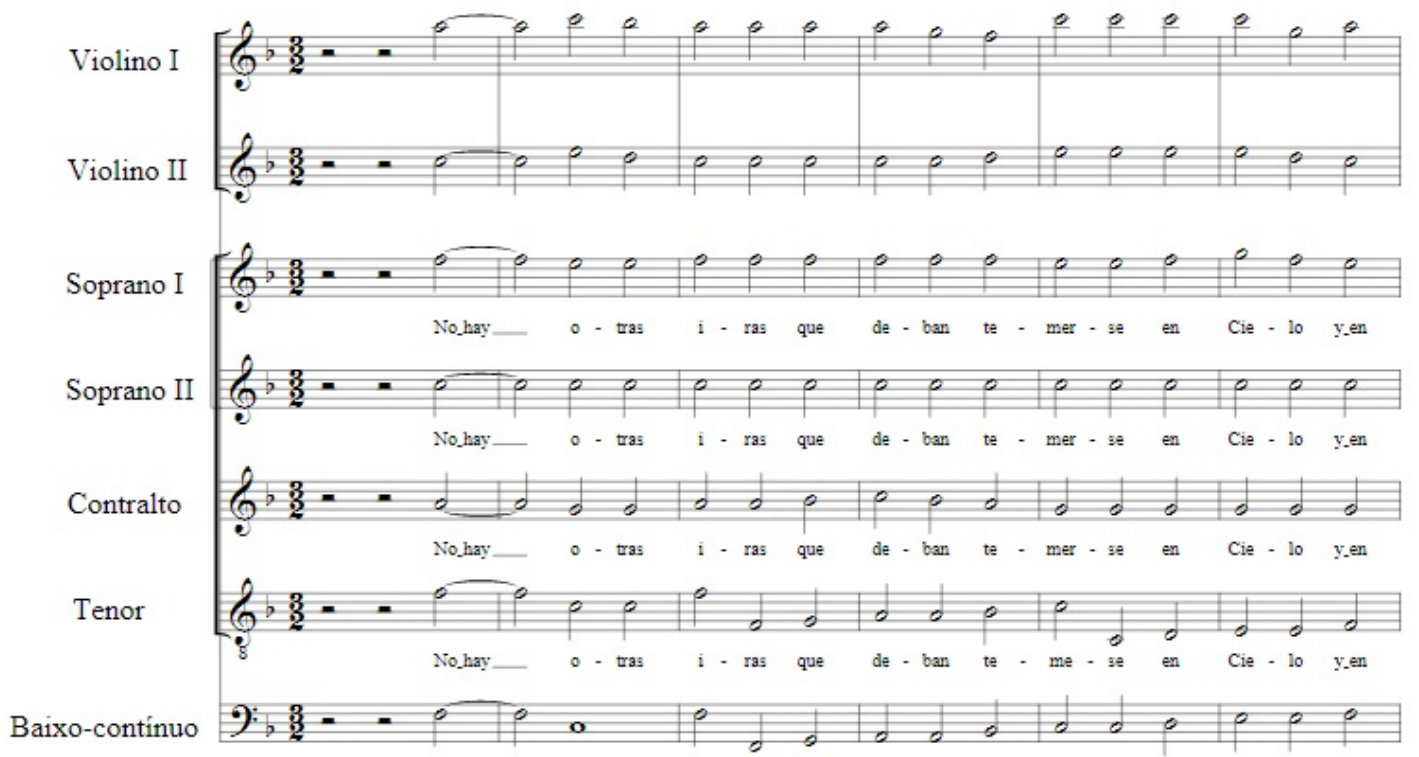

Ex. 5 - José de Cañizares e Antonio Literes. Acis y Galatea. Coro de abertura, c.1-8, p.5.

Para uma melhor compreensão desta passagem, é necessário o conhecimento do que estava acontecendo politicamente na Espanha, no início do século XVIII. Em 1700, com a morte, sem herdeiros, do rei Carlos II (último rei da dinastia dos Habsburgos), inicia-se a Guerra de Sucessão Espanhola. Em seu testamento, Carlos II decreta como seu herdeiro, Felipe, conde de Anjou. O neto de Luis XIV assumirá o cargo em 1701, ao chegar a Madrid. Os demais países europeus, temendo o poder da união entre França e Espanha, apoiam a dinastia dos Habsburgos, cujo representante seria o Arquiduque austríaco Carlos, formando uma aliança entre ingleses, holandeses, austríacos e, posteriormente, portugueses.

No ano de 1705, exércitos anglo-holandeses chegam ao litoral hispânico e o arquiduque é proclamado rei. Felipe $\mathrm{V}$, após perder muito território para os austríacos, acaba retirando-se de Madrid, mas, devido à simpatia que o mesmo despertava nos espanhóis, exércitos voluntários foram incorporados às tropas francesas, devolvendo o trono ao representante dos Bourbons:

Neste momento crítico, a lealdade dos castelhanos salvou a coroa. À frieza com que foram acolhidas as tropas invasoras em Madrid, se somou a resistência das cidades castelhanas que não reconheceram ao arquiduque como soberano. Não se produziu o efeito de adesão em cadência que os aliados esperavam, com a ocupação da capital. Pelo contrário, a hostilidade generalizada os obrigou a abandonar Madrid. (CALVO, 1988, p.51)

Esse mesmo jogo de poderes pode ser observado na zarzuela.

(...) a obra de Cañizares-Literes é a expressão de um conflito de poderes: o do gigante ciclope Polifemo que vê seu território ser tomado por outra divindade, e o da ninfa Galateia, venerada por todos, no mesmo território de Trinacria, onde um dia reinava e aterrorizava seus súditos, Polifemo. (MARROQUÍN, 2004, p.440) 
Os austríacos, que antes reinavam na Espanha, ao tentar retomar seu poder, encontram a população apoiando o monarca francês. Logo, torna-se clara a associação entre o coro acima citado com essa situação ocorrida durante a Guerra de Sucessão.

É possível vincular a figura de Polifemo ao candidato ao trono da dinastia dos Habsburgos. Um fato interessante é que este personagem, apesar de estar entre os protagonistas, possui um papel essencialmente falado, linguagem atribuída aos personagens de baixo nível, e, um dos únicos momentos que canta é para falar com a divindade Galateia.

O gigante, furioso com o culto a Galateia, passa a convencer a população que o melhor será adorá-lo, ressaltando sua nobreza. Este trecho é uma novidade inserida pelo dramaturgo, uma vez que na fábula de Ovídio, Polifemo sempre dirá à ninfa as suas qualidades.

Cuán más útil os será convertir vuestras cadencias en mi aplauso: Hijo soy noble del monarca que gobierna el tripartido tridente con que hiere el mar las tersas repúblicas de sus aguas, donde logra que obedezcan marinas tropas de dioses, (...) náutica deidad le adoran, undoso numen le inciensan.

\author{
Tanto mais útil será \\ que convertam suas cadências \\ em meu aplauso: nobre Filho sou \\ do monarca que governa \\ o tridente tripartido \\ com o qual fere o mar as suaves \\ repúblicas de suas águas, \\ aonde consegue que obedeçam-no \\ tropas marinhas de deuses, \\ (...) \\ divindades náuticas o adoram, \\ númens das ondas o louvam.
}

Esses triunfos marítimos, ainda que metaforicamente, podem estar associados à superioridade naval anglo-holandesa, apoiando os Habsburgos, que no ano de 1704, conquistou Gibraltar e, em 1708, as ilhas de Sardenha e Menorca, além da província de Oran, na Argélia, pertencentes então a Espanha. Esse domínio devia-se não somente à maior quantidade de navios, mas também à melhor condição destes e das tripulações.

Polifemo segue em seu discurso, afirmando que se a sua descendência não é suficiente, um bom motivo para que o cultuem é a sua grandeza.

Y cuando el ser yo quien soy mis méritos no os dijera, esta gigante estatura ¿no os explica mi grandeza? (...) Yo soy aquél que si el día tal vez a enojarme llega puesto en pie, a la inmensa sombra que mi adusto cuerpo ostenta, a mediodía consigo que dos orbes anochezcan.

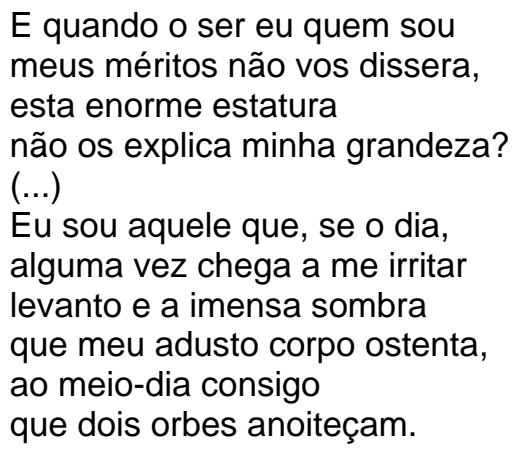


A sua descrição é de tamanha grandeza, que o gigante, conseguiria cobrir com a sua sombra dois mundos, mesmo ao meio dia. Ou seja, nada para ele é impossível. O ciclope passa a fazer promessas aos seus seguidores, afirmando que poderão ter tudo o que quiserem, já que imensa é sua força física:

Si me dais adoración,

Trinacrios, nada hay que sea

difícil para vosostros;

pues si queréis que dé vuelta

el orbe porque gocéis

la luz del sol de más cerca,

en levantando yo un brazo

esa máquina primera

del cielo desfijaré

hasta que a mi impulso atenta

disponga a mi arbitrio el orden

de Signos y de Planetas.

\author{
Se me ofereceis adoração, \\ Trinacrios, não há nada que seja \\ difícil para vós; \\ pois se quereis que dê volta \\ o orbe porque gozeis \\ da luz do sol mais perto, \\ ao levantar um braço \\ essa máquina primeira \\ do céu arrancarei \\ até que a meu impulso alerta \\ disponha ao meu arbítrio a ordem \\ de Signos e de Planetas.
}

Toda essa caracterização dada pelo ciclope busca ao mesmo tempo surpreender a população, mas principalmente assustar, soando quase como uma ameaça. Mais uma vez este trecho pode ser comparado a uma situação semelhante ocorrida durante a Guerra de Sucessão.

Em 1702, as frotas anglo-holandesas preparavam-se para um ataque a Cádiz. Entretanto, devido a uma carta escrita pela rainha, com forte caráter religioso, as populações vizinhas, na região de Andaluzia, auxiliam na defesa da cidade. As esquadras aliadas acabam realizando apenas saques em algumas cidades. Essa situação causou muito receio na população, constantemente ameaçada pelo poderio naval inglês e holandês.

As consequências que se derivaram deste feito, para as pretensões do arquiduque foram muito negativas. $O$ duro saque, a que se submeteram estas povoações, manchou a imagem dos aliados. Além disso, a notícia dos excessos e roubos cometidos em igrejas e conventos, convenientemente manipulada pela propaganda felipista, marcou de forma tenebrosa o seus autores. (CALVO, 1988, p. 29)

Os ingleses e holandeses, que já tinham fama de hereges na Espanha, passam a sofrer os danos com essa propaganda de cunho essencialmente religioso, e, não por acaso, nesta peça, o arquiduque Carlos está associado à figura de Polifemo, que, de acordo com toda a tradição literária ${ }^{14}$, não possui nenhum tipo adoração aos deuses, somando-se a este fato sua imensa barbárie.

Nos versos finais de sua fala, há uma repreensão aos súditos, os quais poderão ter todas as coisas que desejarem,

Menos una, y es que yo ni Amor ni que améis consienta, pues no sé que pueda haber
Menos uma e é que eu nem Amor, nem que ameis concederei, pois não sei se pode haver 
más miserable bajeza en mi propio vencimiento aplaudir mi misma afrenta mais miserável baixaria à minha própria vitória aplaudir minha afronte.

Esta censura feita aos súditos, com relação ao amor, é facilmente explicada, uma vez que o mesmo está associado à figura de Galateia, ao longo de toda a obra, como afirma MARROQUín (2004, p.441): "Através de seu único olho, o orgulhoso ciclope contempla como seu povo, de pastores e zagais, cedeu ao senhorio do Amor, personificado no novo domínio de Galateia."

Com a entrada do personagem Ácis, logo depois da cena acima, o trecho abaixo é repetido seis vezes, alternando-se com momentos de fala e de canto.
Ay de aquél que desprecia
Ai, daquele que desdenha
el poder del amor y la belleza.
o poder do amor e da beleza.

O Ex.6 demonstra como era a música utilizada para persuasão. Trata-se de uma melodia simples, que, em todas as seis vezes, não apresenta nenhuma alteração, apenas intensifica a ideia em cada vez que é cantada. Neste momento o povo da Trinacria acaba de aceitar Polifemo como a nova divindade a ser cultuada no local, ao invés de Galateia, que como já visto, é a personificação do amor. Portanto, aquele que desdenha o poder do amor, estaria desdenhando também, Galateia.
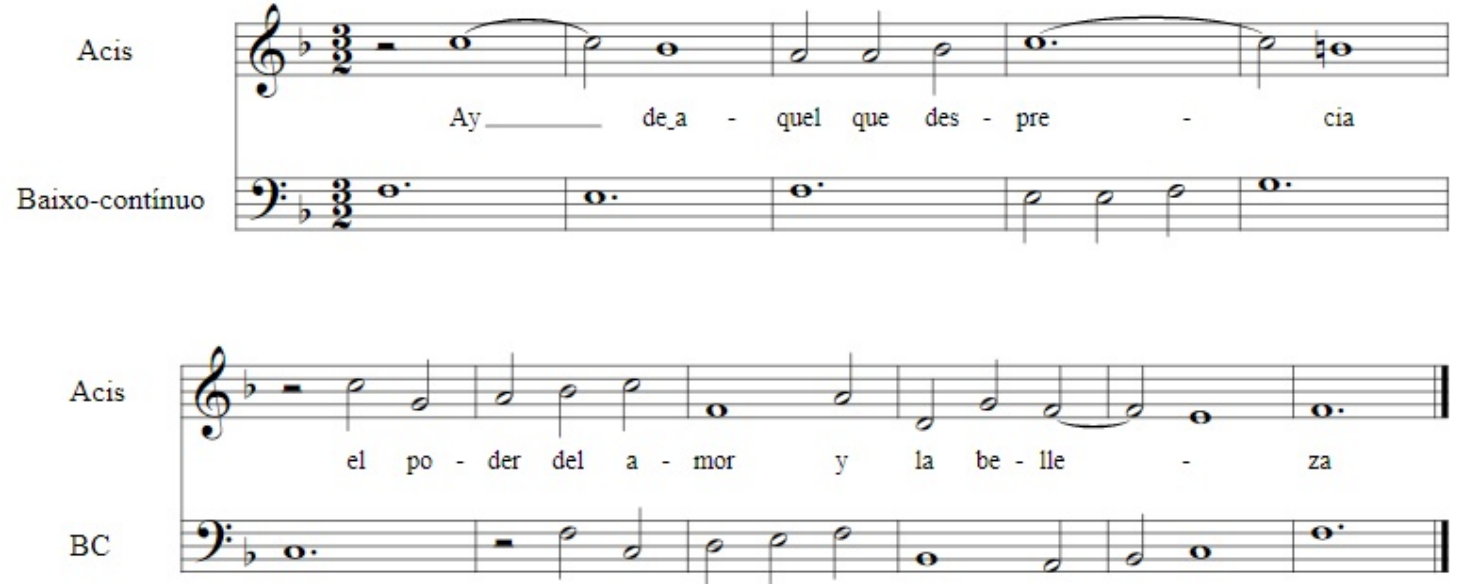

Ex. 6 - José de Cañizares e Antonio Literes. Acis y Galatea. Estribilho cantado por Ácis, c.1-11, p.14.

Essas pequenas intervenções musicais adquirem um papel muito importante para a persuasão, bem como para o caráter moralizante da peça, pois une os elementos retóricos musicais com os textuais, possuindo, portanto, mais força do que uma música unicamente instrumental. Logo, esta advertência de Ácis é, na realidade, um aviso ao próprio povo espanhol de que o poder de Felipe $\mathrm{V}$ não seja subestimado. 
Ao mesmo tempo em que Polifemo é associado ao arquiduque Carlos da Áustria, a figura de Galateia está diretamente relacionada à imagem do próprio rei Felipe $\mathrm{V}$, cujo reinado, por sua vez, representaria um governo de amor.

Polifemo (representando o arquiduque austríaco), por outro lado, diferencia-se de Galateia (Felipe V), pois constrói seu domínio ao provocar medo na população. A fala do personagem Momo reflete a obrigação em servi-lo:

\section{MOMO}

Puesto que allí le descubro, venid, que hacia allí me manda que lleguemos, repitiendo su victoria en voces altas.

\author{
MOMO \\ Pois ali o vejo, \\ vinde, que até ali ele mandou \\ que fôssemos, repetindo \\ sua vitória em vozes altas.
}

Nesse momento, o povo da Trinacria entra no palco e depara-se com Polifemo aos pés de Galateia; a reação é de estranhamento, mas observa-se também certa ironia na última frase do personagem Telemo, ao interrogar se aquelas eram suas façanhas, assim como na fala de Tisbe, ao questioná-lo sobre sua valentia:

POLIFEMO

¿Qué os espanta?

TELEMO

Que cuando, de parte tuya, oh, Polifemo, nos llaman a celebrar tus blasones, te hallemos puesto a las plantas de la deidad que desprecias.

TÍNDARO

¿No eras tú el que aconsejaba que el templo de Galatea a tu honor se dedicara?

DORIS

¿No eras tú quien al Amor baldonaste con jactancia?

TISBE

¿No era Su Largueza quien nos echó cien mil fanfarrias?

TODOS

Pues ¿cómo a los pies te postras de aquello mismo que ultrajas?

TELEMO

¿Ésta es la hazaña y el triunfo a que nos convocas?

\author{
POLIFEMO \\ O que os espanta?
}

TELEMO

Que quando, ao teu pedido, oh, Polifemo, nos chamam para celebrar tuas glórias te encontramos aos pés da divindade que desdenha.

\section{TÍNDARO}

Não eras tu que aconselhavas que o templo de Galateia a tua honra se dedicasse?

DORIS

Não era tu quem ao Amor insultaste com jactância?

TISBE

Não era Sua Largueza ${ }^{15}$ quem nos deu cem mil fanfarrices?

\section{TODOS}

Pois, como aos pés te pões daquele mesmo que ultrajas?

\section{TELEMO}

Esta é a façanha e o triunfo ao qual nos chama?

Em 1708, na estreia de Acis y Galatea, a Guerra de Sucessão Espanhola ainda não havia terminado, entretanto, muitas conquistas foram feitas pelos Bourbons 
nesse período. Devido ao apoio popular conquistado por Felipe, o arquiduque austríaco se viu obrigado a retirar-se de Madrid, restabelecendo-se em Valência, cidade que foi reincorporada à coroa espanhola, durante a Batalha de Almansa, conflito ocorrido em 1707. No trecho acima, metade da primeira jornada, Polifemo acaba curvando-se aos poderes de Galateia, e, cantando junto ao coro, reconhece suas glórias.

Pues que Galatea todo lo avasalla y hasta Polifemo la sirve y la ama, venid con aplauso, con música y salva a cantar sus glorias a ver sus hazañas.

\author{
Pois que a Galateia \\ Todos se submetem \\ e até Polifemo \\ serve-a e ama-a \\ vinde com aplauso, \\ com música e \\ cantar suas glórias \\ e ver suas façanhas.
}

Pode ser observado o predomínio da escrita homofônica para o coro, no qual o próprio personagem protagonista não é destacado das demais vozes. Cabe lembrar, que o coro, não apenas desta peça, mas da maioria das obras compostas neste período, era constituído por soprano I e II, contralto e tenor.

Como pode ser verificado Ex.7, Polifemo cantaria o tenor, o que, de certa forma, vai contra toda tradição musical ${ }^{16}$, em que o mesmo é representado por um baixo. Este é outro elemento para dar uma caracterização bizarra ao gigante, já que causaria grande estranhamento ao público, a grande e poderosa figura mitológica possuir uma voz aguda. É importante ressaltar a constante associação entre o personagem e o Arquiduque Carlos.

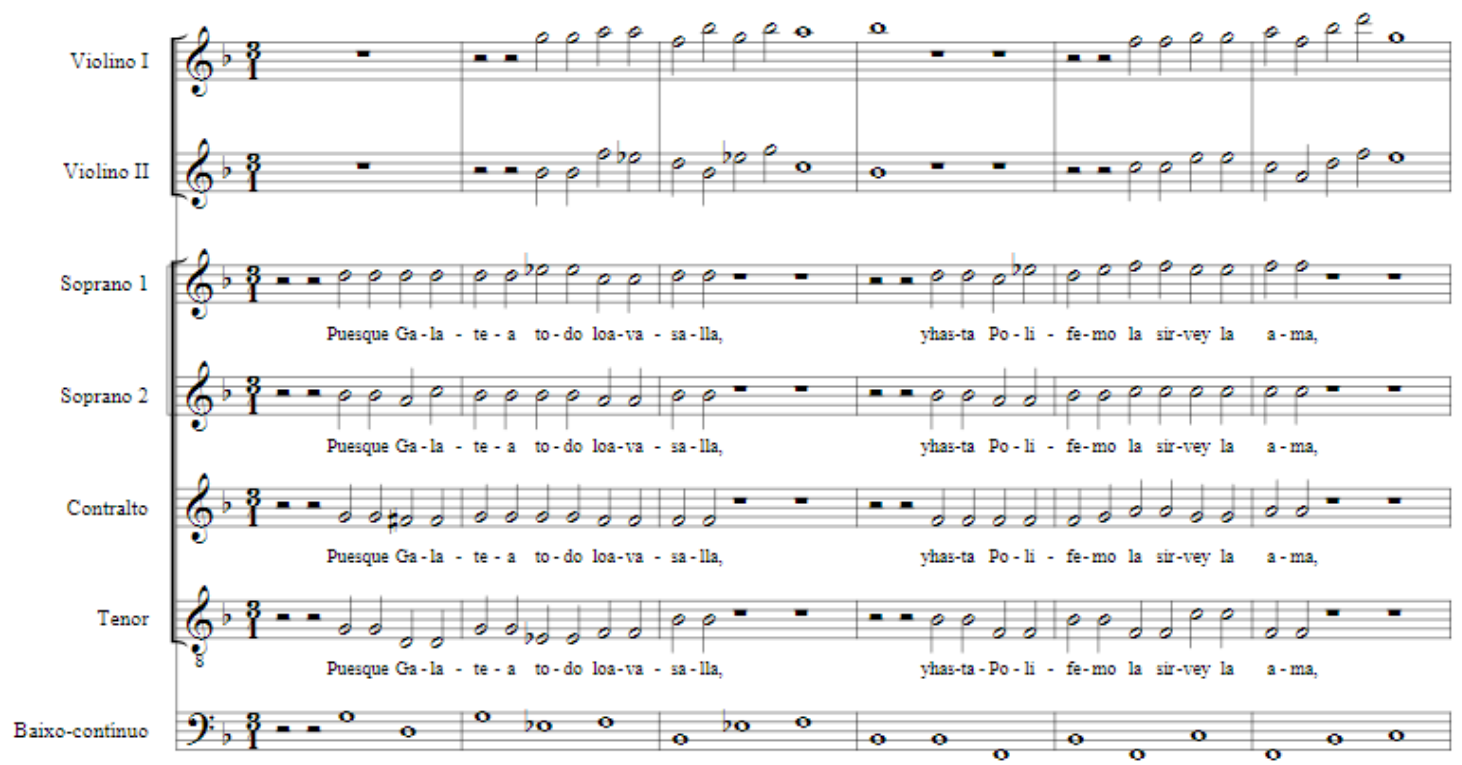

Ex.7 - José de Cañizares e Antonio Literes. Acis y Galatea. Coro Pues que Galatea todo lo avasalla, c.1-6, p.58.

Nesta zarzuela, além dos trechos acima exemplificados, encontra-se outro elemento comum do teatro espanhol que são os personagens estereotipados, 
dentre os quais podem ser destacados Momo e Tisbe, que juntos formam a pareja de graciosos (casal de graciosos). Estes personagens estão presentes em praticamente toda peça teatral desde o século XVI, caracterizados pelo seu papel bufo, com linguagem essencialmente coloquial. No trecho abaixo, após a população se render à Polifemo, o casal, através de linguagem cotidiana e de ironias fazem oferendas ao gigante.

\section{MOMO}

Y si acaso como cuentan su merced ofrendas humanas admite, cuando se almuerza dos hombres en estofado y una mujer en conserva, aquí le presento una que, a un lado el asco, en su mesa pueda zampársela, pues sólo para asada es buena.

\section{TISBE}

Y si su Gigantidez gusta de caza de bestias, llévese allá mi marido, llevará la mayor dellas.

\author{
MOMO \\ E se por acaso como contam \\ sua mercê oferendas humanas \\ aceite, quando se almoça \\ dois homens ensopados \\ e uma mulher em conserva \\ aqui o apresento uma \\ que, apesar do asco, em sua mesa \\ pode engoli-la, pois \\ somente para assar é boa.
}

TISBE
E se sua Gigantude ${ }^{17}$
gosta de caça de bestas
leve junto meu marido,
levará a maior delas.

TISBE

E se sua Gigantude ${ }^{17}$ leve junto meu marido, levará a maior delas.

De acordo com Marroquín, personagens com este perfil "mostrar-se-iam mais inclinados ao riso fácil e à expressão das paixões e defeitos alheios" (2004, p.434). Musicalmente também há uma diferenciação com relação aos demais personagens. Uma vez que representam papéis simples, a música que cantarão tende a ser menos elaborada, e, muitas vezes, já conhecida pelo público, pois em geral, eles serão responsáveis pela persuasão das classes mais baixas, causando assim uma identificação com a audiência.

No trecho seguinte, Tisbe pergunta a Momo o que aconteceu com Ácis e Galateia. O acompanhamento é feito somente pelo baixo contínuo, a melodia bastante repetitiva será apresentada por Tisbe e reapresentada por Momo, 0 compasso é ternário (atribuído aos personagens tipicamente espanhóis ${ }^{18}$ ), como pode ser visto no Ex.8.

\section{TISBE}

Desgraciado gracioso

a quien Amor ha hecho

ridícula figura

deste cómico enredo

(...)

MOMO

Endemoniada ninfa

que en contrarios aquellos

en latín me amenazas

para aburrirme en griego

\section{TISBE}

Desgraçado gracioso

a quem o Amor fez

ridícula figura

deste cômico enredo

(...)

MOMO

Demoníaca ninfa

que ao contrário daqueles

em latim me ameaça

para aborrecer-me em grego 
A presença de palavras coloquiais, bem como as rimas nos versos pares ${ }^{19} \mathrm{e}$ livres nos demais, ressaltam o caráter espanhol deste trecho, caracterizando-o também como um romancillo, forma muito encontrada na literatura hispanica.
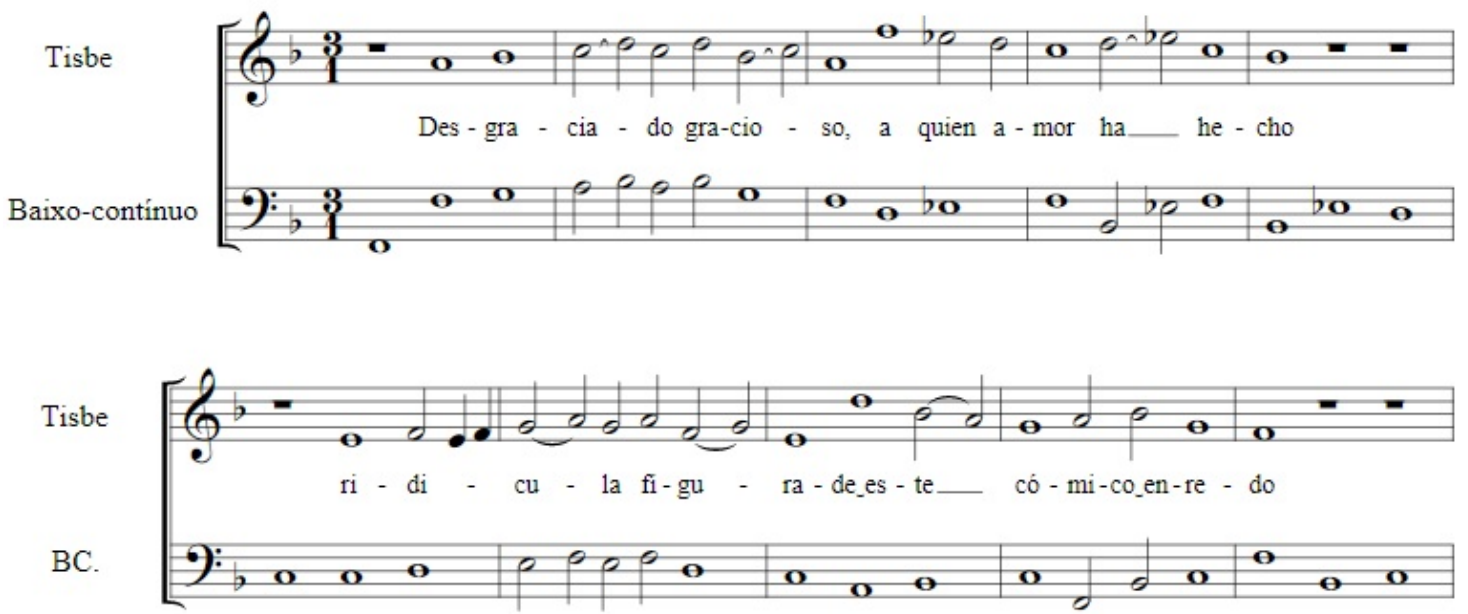

Ex.8 - José de Cañizares e Antonio Literes. Acis y Galatea. Canção espanhola em forma de romancillo, c.1-10, p.97.

O papel de Polifemo, como já foi afirmado acima, estaria associado ao arquiduque austríaco, pretendente ao trono espanhol da dinastia Habsburgo, representando, portanto, um papel mais elevado. Entretanto, a forma como o mesmo é retratado na zarzuela, é a mesma de um personagem comum à classe baixa, onde há predomínio da fala, embora a linguagem, diferentemente dos demais personagens que não cantam, seja bastante elaborada, seguindo um dos princípios da verossimilhança teatral espanhola.

Dulce Galatea,

pues Amor me ha hecho

de tu hermosa ira

infeliz objeto,

ay tirano dueño,

más duro que el bronce

es tu ingrato pecho,

puesto que le ablando

y no le enternezco.

Como a heroica reina

del marino imperio

te labro el tridente

que será tu cetro.
Doce Galateia,

pois Amor me fizeste

da tua linda ira

infeliz objeto,

ai tirano dono,

mais duro que o bronze

é teu ingrato peito

posto que o suavizo

e não o comovo.

Como a heroica rainha

do marinho império

te lapido o tridente

que será teu cetro.

Apesar do texto elaborado, os trechos musicais, por sua vez, não são de grande complexidade, baseados em melodias simples e repetitivas, com um contraponto bastante simples de primeira espécie e no em compasso ternário. No Ex.9, pode-se observar a semelhança desta canção com as citadas acima, no Ex.8, de personagens considerados mais baixos. 

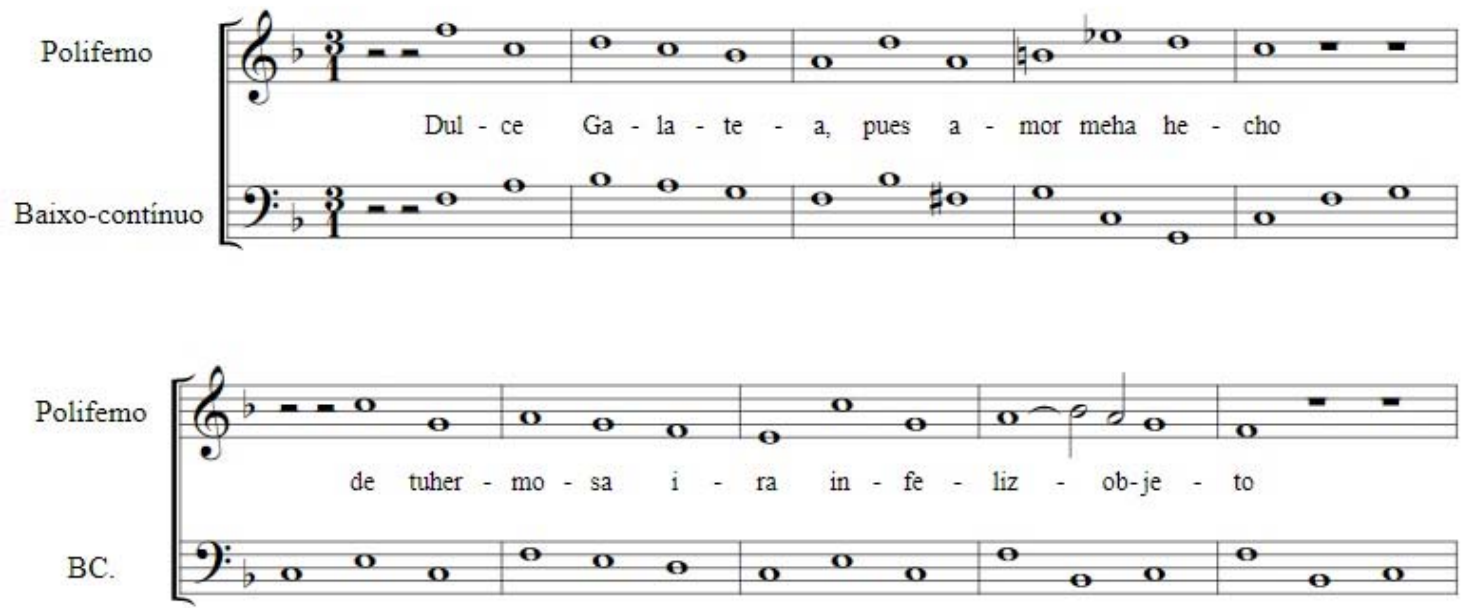

Ex.9 - José de Cañizares e Antonio Literes. Acis y Galatea. Canção de Polifemo, c.1-10, p.111

É provável que o motivo do tratamento dado ao personagem tenha caráter político e doutrinário. Se o papel de Polifemo fosse cantado, assim como o de Galateia, seria o mesmo que equiparar Felipe $\mathrm{V}$ ao arquiduque Carlos, o que poderia exercer um efeito não desejado na população.

Polifemo, apesar de sua força, em nenhum momento da obra é temido por Galateia, que inclusive o enfrenta, após as oferendas a ela dadas pelo ciclope, na frente de toda população. Estes elementos diferenciam esta versão de Acis y Galatea das demais versões da fábula de Ovídio, em que a ninfa é intimidada pelo gigante. Novamente, encontra-se uma forte propaganda por trás desta alteração: Felipe $V$ não teme seu adversário, e mais do que isso, é capaz de encará-lo, se necessário.

Na zarzuela, neste momento, encontra-se uma Ária da Capo, na qual Polifemo é repudiado por Galateia, com muitos elementos do stilo concitato ${ }^{20}$, com elaboração musical muito mais complexa.

Cielo ha de ser el mar,

mar el Cielo ha de ser,

el incendio ha de helar, la nieve arder, primero que lograr

tu fino proceder

que pueda yo estimar

horror que he de olvidar y aborrecer.
Céu há de ser o mar, mar o Céu há de ser, o incêndio gelará, a neve arderá, primeiro que conseguir teu fino comportamento que eu possa estimar horror que hei de esquecer e odiar.

No Ex.10, verifica-se que o início da ária, com movimentos rápidos e extensos dos violinos em uníssono, deixa claro para o ouvinte, ou o intérprete, o caráter agitado desta peça. 


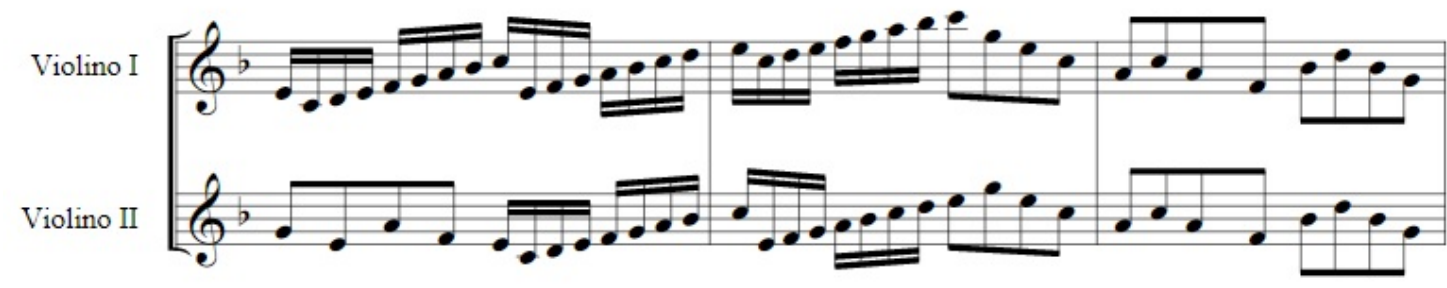

Ex.10 - José de Cañizares e Antonio Literes. Acis y Galatea. Abertura da ária de Galateia, c.20-22, p.126.

Uma movimentação semelhante é realizada pela personagem, em um momento de expressão de ódio e aversão a Polifemo, como pode ser observado no Ex.11 abaixo.

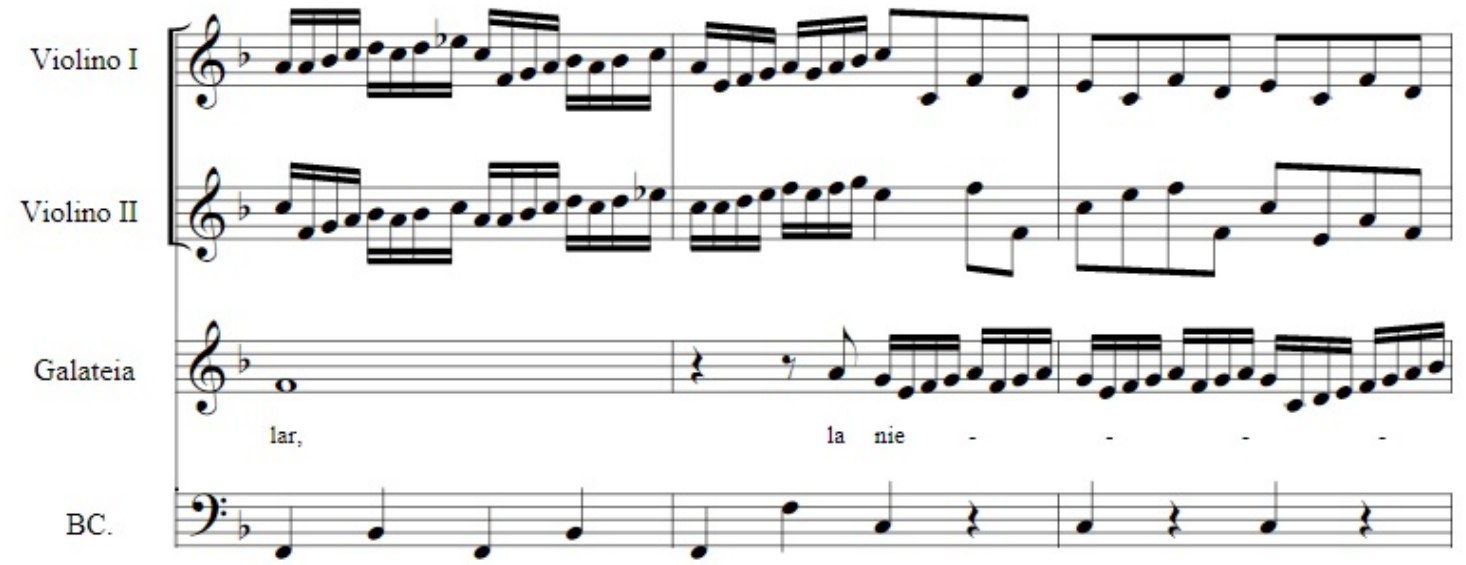

Ex.11 - José de Cañizares e Antonio Literes. Acis y Galatea. Trecho cantado da Ária de Galateia, c.36-37, p.128

O baixo-contínuo segue esta mesma caracterização, movimentando-se, essencialmente, através de colcheias, como mostra o Ex.12.

Baixo-contínuo

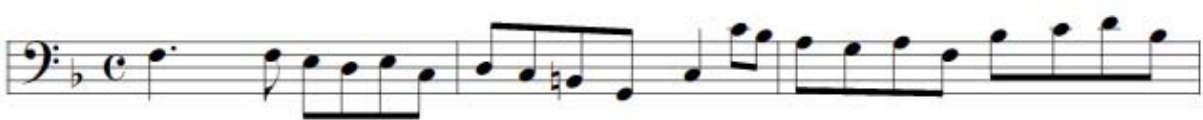

Ex.12 - José de Cañizares e Antonio Literes. Acis y Galatea. Abertura da ária, baixo-contínuo, c.20-22, p.126.

A Ária da Capo, forma italiana, é, em geral, associada aos personagens divinos. A linha do canto possui uma extensão maior, além da presença de coloraturas e notas alteradas, em compasso quaternário. Ao mesmo tempo, é possível reparar um contraponto entre a melodia e o baixo-contínuo, bastante característico ao barroco tardio. O emprego de elementos estrangeiro possui um simbolismo muito forte, pois ainda em inícios do século XVIII, não era bem aceito pela população espanhola. Por essa razão, os mesmos eram usados somente para representação da nobreza, os únicos que seriam capazes de compreender tais elementos, enquanto as formas mais simples eram deixadas para os personagens mortais, ou seja, a plebe. 
O gigante, muitas vezes, é tratado de forma caricata pelos próprios personagens populares, em especial pelos graciosos.

TISBE

Está el Gigante, por cierto, para tarasca barbuda, hecho un ángel del Infierno.
TISBE

Está o Gigante, certamente, mais para uma tarasca barbuda, feito um anjo do Inferno.

Polifemo, ao mesmo tempo em que é temido pela população de Trinacria, é ridicularizado pela mesma, como pode ser verificado na passagem acima. É ainda possível, atribuir uma dualidade ao caráter do personagem, quando Tisbe refere-se ao mesmo como "anjo do Inferno". O gigante, ao chegar a Trinacria, promete ser capaz de realizar qualquer façanha, através de atos simples, descreve-se como possuidor de uma grandeza inconcebível para a população e ainda afirma que os libertará da prisão, que nada mais é que o reinado de amor de Galateia. Entretanto, o seu comportamento, causador de medo, combinado à sua figura grotesca, demonstra o inverso. Mais do que isso, através dessa metáfora, também se faz uma alusão ao caráter herege dada à causa dos Habsburgos pelos Bourbons e aos demais fatos sucedidos durante a guerra, como os vários saques feitos às cidades litorâneas.

A associação do gigante a Tarasca, por sua vez, possui outro papel importante na propaganda de Felipe $V$. De acordo com a crença popular, a Tarasca era um monstro mitológico bastante temido, que devastava todo lugar em que passava. Era descrito como um dragão, com seis patas curtas, semelhantes às de um urso, com o torso parecido ao de um boi, com carapaça de tartaruga e uma cauda escamosa. A cabeça seria a de um leão com orelhas de cavalo, com uma expressão desagradável. Era bastante comum a representação desta criatura durante as festas de Corpus Christi. Conta a lenda que a Tarasca lembrando o paralelo entre Polifemo e o Arquiduque austríaco - teria sido derrotada por Santa Marta, conquistando muitos fiéis ao libertar a população do monstro. Ou seja, o mesmo papel exercido por Galateia na peça, ao derrotar Polifemo, logo, pelo novo monarca, Felipe V, que certamente venceria o outro candidato ao trono.

O único momento da peça em que Polifemo demonstra um gesto nobre é quando se curva a Galateia, mas mesmo assim é visto pelos demais personagens de maneira irônica e até mesmo bizarra, como já foi explicado anteriormente.

\section{Conclusão}

Em plena Guerra de Sucessão, a propaganda política como meio de exaltação ao novo rei era fundamental para estabelecer um reinado duradouro e aceito pela população. Felipe $\mathrm{V}$, sendo neto do monarca francês, o maior exemplo de absolutismo na Europa no período, deveria demonstrar todo esse poderio. Como afirma Castro, 
Luis XIV queria na Espanha uma monarquia mais absoluta e centralizada, ao modo francês; (...) Tinha-se que começar colocando fim à etiqueta dos Austríacos, que mantinha o rei enclausurado e acessível somente aos grandes da Espanha; tinha-se que ressaltar seu prestígio, tornando-o visível ante a generalidade da nobreza e o povo; tinha-se que conseguir que o palácio tivesse um papel político de exaltação do soberano, como em Versalhes. (2004, p.43)

A propaganda política foi um meio utilizado pelos dois pretendes ao trono, sempre buscando "legitimar os direitos e atuações de cada um, ao mesmo tempo em que buscava a desqualificação do inimigo." (CALVO, 1988, p.49). Era fundamental, por um lado, exaltar a figura de Felipe $\mathrm{V}$, por outro, passar uma imagem negativa do Arquiduque Carlos.

O teatro foi um meio bastante eficaz para propagar a imagem pretendida por Luis XIV para seu neto. Nesta zarzuela há tantos elementos de consagração a Felipe $\mathrm{V}$, e, de propaganda política, encontradas de diferentes maneiras, como por exemplo, na caracterização dos personagens: Galateia, incorporando uma figura boa, amorosa e piedosa, representando Felipe $\mathrm{V}$, enquanto Polifemo, assustador e orgulhoso, simulando o candidato austríaco ao trono.

Um dos elementos principais para a propaganda felipista, aqui apresentado, foi o cunho religioso que a campanha adquiriu. A França e, especialmente, a Espanha, eram países católicos, com um grande domínio da igreja, diferentemente da Holanda e da Inglaterra, considerados pagãos devido ao repúdio dessa religião, o que não deixa de ser um reflexo do caráter de Polifemo. Logo, ressaltar essa aversão ao catolicismo foi fundamental para a conquista da população, bem como para o êxito da dinastia Bourbon.

Musicalmente, observa-se o papel retórico de alguns trechos, como o que é cantado por Acis, como já foi demonstrado no Ex.6 acima, advertindo para que não se desdenhe o poder do amor (Galateia - Felipe $V$ ). A repetição deste trecho tem a ver com a persuasão, e, metaforicamente tem um significado muito importante: que não se despreze o poder de Felipe $\mathrm{V}$.

A incorporação de características típicas do teatro espanhol, como o casal de graciosos, comunicando-se através de seu modo de falar peculiar, apresentados juntamente com elementos muito comuns na ópera francesa: a glorificação do rei e de seus grandes feitos, como canta uma das nereidas e a presença do minueto ao final da peça ${ }^{21}$, ao invés do típico baile. Esta união foi essencial para comunicação direta com o povo e também com a nobreza.

$\mathrm{Na}$ realidade, a própria festa teatral era um evento propagandístico, através de toda sua riqueza, cenários, trajes, música e danças, o mesmo atuava de maneira positiva no público, uma vez que "a grandeza da corte de Luis XIV seduzia a nobreza de Castilla, desejosa de imitar as festas de Versalhes no palácio madrileno." (CALVO, 1988, p.50) 


\section{Referências}

ASENSIO, María Asunción Flórez. Teatro Musical Cortesano en Madrid durante el siglo XVII: Espacios, Intérpretes y Obras. Madrid: Universidad Complutense de Madrid, 2004.

BUSSEY, William M. French and Italian Influence on the Zarzuela 1700-1770. Michigan: UMI Research Press, 1980.

CALVO, José. La Guerra de Sucesión. Madrid: Grupo Anaya S.A., 1988.

CAÑIZARES, José. Acis y Galatea. Madrid: Iberoamericana, 2011.

CASTRO, Concepción de. A la sombra de Felipe $V$ - José de Grimaldo, ministro responsable (1703-1726). Madrid: Marcial Pons Historia, 2004

GONZÁLEZ MARÍN, Luis Antonio. Introducción. In: Acis y Galatea - zarzuela en dos jornadas. Madrid ICCMU, 2002.

LITERES, Antonio. Acis y Galatea - zarzuela en dos jornadas. Madrid: ICCMU, 2002.

LOPEZ CANO, Rúben. Música y Retórica en el Barroco. México: UNAM, 2000.

MARROQUíN, Lucía Diaz. La nieve arder: retórica afetiva en el universo petrarquista de la zarzuela Acis y Galatea. In: Revista de Literatura. Madrid: Consejo de Investigaciones Cientificas, 2004, p.431-464.

STEIN, Louise K.. Songs of Mortals, Dialogues of the Gods - Music and Theatre in the Seventeenth-Century Spain. New York: Oxford University Press Inc., 1993.

${ }^{1}$ Vide STEIN, Louise K. Opera and the Spanish Political Agenda. In: Acta musicological, 63 (1991).

2 Segundo Calvo (1988), a nobreza, na realidade, ocupava um lugar de prestígio social, mas possuía pouquíssimo poder, ocupando-se, portanto, com festas (dentre as quais estão as fiestas de zarzuela) e caças.

${ }^{3}$ Todas as traduções presentes neste trabalho foram realizadas pela própria autora do artigo.

${ }^{4}$ Para maiores informações sobre o assunto recomenda-se a leitura de El arte nuevo de hacer comedias en este tiempo, de Lope de Vega, bem como Songs of mortals, dialogues of the gods, de Louise K. Stein.

${ }^{5}$ É importante lembrar que os compositores de música de Igreja, na maioria das vezes, eram os mesmos que compunham para as grandes representações teatrais. Por esse motivo, críticas aos estrangeirismos na música espanhola do período, são encontradas em documentos da época, principalmente El theatro critico universal do Padre Benito Feijoó.

6 Encontra-se nas zarzuelas deste período uma predominância dos gêneros vocais e pouquíssimos momentos instrumentais. As aberturas das peças serão cantadas e até mesmo as danças possuem trechos vocais.

${ }^{7}$ As nereidas eram ninfas marítimas, filhas de Nereu e Dóris. Diferentemente das ninfas dos bosques, as nereidas eram imortais. Dentre as mais conhecidas estão Tétis - mãe de Aquiles e Galateia.

8 Todos os exemplos do texto poético desta zarzuela foram retirados do libreto de José de Cañizares, que antecede a versão moderna da partitura, ambos editados por González Marín.

${ }^{9}$ Maria Luisa e Luis são, respectivamente, a rainha e o príncipe herdeiro.

10 Para o presente artigo foi utilizada a edição crítica de Acis y Galatea, realizada por Luis Antonio González Marín. A mesma foi realizada a partir dos dois manuscritos existentes da obra, que se encontram em Madrid, na Biblioteca Nacional de España, e em Évora, na Biblioteca Pública de Évora.

${ }^{11}$ Luis Antonio González Marín, responsável pela edição moderna de Acis y Galatea, realizou um estudo com as partituras existentes da obra, entretanto, acredita-se que nenhuma delas seja a versão original, feita para a comemoração do aniversário de Felipe V, no ano de 1708. A primeira delas, localizada na Biblioteca Nacional de España, data de 1709, enquanto a segunda, sem data, localizada na Biblioteca Pública de Évora, referente, provavelmente, a alguma apresentação da zarzuela em Portugal. Por outro lado, é de conhecimento dos 
pesquisadores de música deste período, que a adaptação de obras, para que melhor se adequassem ao local aonde seriam apresentadas, bem como aos músicos (neste caso também atores) que as executariam, era bastante comum.

12 "Jornada" é um termo utilizado no teatro espanhol para substituir "ato", pois estaria mais de acordo com a concepção de tempo das obras teatrais. Para mais informações vide La teoría y formas dramáticas en el siglo XVI, em História del Teatro Español, de Javier Huerta Calvo.

${ }^{13}$ Trinacria é o antigo nome grego atribuído à ilha de Sicilia, na época, território espanhol.

${ }^{14}$ A primeira referência ao ciclope é na Odisseia de Homero, onde é descrito como um bárbaro, sem leis, que não cultua aos deuses e alimenta-se de humanos. Esse caráter de Polifemo é recorrente em diversas obras.

15 "Sua Largueza" trata-se, na realidade, de uma forma irônica que o dramaturgo encontra para que os personagens mais baixos se refiram a Polifemo, ressaltando, inclusive o quão grotesco o mesmo seria.

16 Por exemplo, nas obras de Loreto Vittori (1600-1660) - La Galatea (1639), G.F.Händel, Jean Baptiste Lully (1632-1687) - Acis et Galatée (1686), George Friedrich Händel (1685-1759) - Aci, Galatea e Polifemo (1708) e Acis and Galatea (1719), que na realidade, refletem a literatura, na qual o ciclope teria uma voz muito grave.

17 "Gigantidez" não possui uma tradução para o português, mas aqui, é utilizada como uma forma coloquial de atribuir o título de nobreza ao gigante, assim como "Su Largueza" foi utilizado anteriormente.

${ }^{18}$ Há certas características típicas da música espanhola, que são listadas por José López-Calo, em Historia de la música española - siglo XVII, as quais estariam presentes nas canções dos personagens mais simples.

${ }^{19}$ Reparar na rima e-o, em hecho, enredo, aquellos, griego.

20 O stilo concitato é definido por Monteverdi, no prefácio de Madrigali guerreri, et amorosi (1638). Caracteriza-se pelo tempo rápido, com a divisão da semibreve em dezesseis semicolcheias, combinando com palavras que expressem raiva, sempre movido pelo afeto da guerra.

${ }^{21}$ No final da zarzuela há a seguinte indicação "Pasan las tramoyas y tomando sus puestos danzan un Minué", ou seja, após a retirada do maquinário e cenário, dançam um Minueto.

lara Luzia Fadel Rodriguez é mestre em música pela UFPR, sob a orientação da Profa. Dra. Silvana Scarinci. Graduou-se como bacharel em música habilitação em canto, pela UFRGS, em 2010, instituição na qual atuou em projetos como "Música para Bebês", com orientação de Esther Beyer, e foi ministrante no curso de extensão em instrumentos da universidade, na área do canto. Atualmente é aluna do curso de doutorado em musicologia da UNICAMP, sob a orientação do Prof. Dr. Paulo M. Kühl. Sua pesquisa concentra-se essencialmente sobre a música teatral espanhola, da primeira metade do século XVIII, dando ênfase aos gêneros espanhóis, abordando convenções espanholas e estrangeiras presentes nestas obras. Interessa-se pelo estudo envolvendo e misturando diversas áreas do conhecimento, buscando compreender não apenas um evento de maneira isolada. 